Patterson, M.E., C.C. Doughty, S.O. Graham, and B. Allan. 1967. Effect of bruising on postharvest softening, color changes and detection of polygalacturonase enzyme in cranberries. Proc. Amer. Soc. Hort. Sci. 90:498-505.

Pepin, H.S. and D.M. Boone. 1995. End rot, p. 36-37. In: F.L. Caruso and D.C. Ramsdell (eds.). Compendium of blueberry and cranberry diseases. ASP Press, St. Paul, Minn.

Ringel, S.M., J. Kaufman, and M.J. Jaffe. 1959. Refrigerated storage of cranberries. USDA Mktg. Res. Rpt. 312.

Roper, T.R. and N. Vorsa. 1997. Cranberries: Botany and horticulture. Hort. Rev. 21:215-249.

Spayd, S.E., J.R. Morris, W.E. Ballinger, and D.G. Himelrick. 1990. Maturity standards, harvesting, postharvest handling, and storage, p. 504-531. In: G.J. Galleta and D.G. Himelrick (eds.). Small fruit crop management. Prentice Hall, Upper Saddle River, N.J.

Stark, R., F.R. Forsyth, C.L. Lockhart, and I.V. Hall. 1974. Processing quality of cranberries after extended storage in $\mathrm{N}_{2}$ atmosphere with low and high relative humidities. Can. Inst. Food Sci. Technol. J. 7:910 .

Stark, R., I.V. Hall, F.R. Forsyth, and P.R. Dean. 1969. Cranberries, evaluated for fresh fruit and processing quality, after reduced oxygen storage. Cranberries $37(6): 14,16$ and $37(7): 14,16$.

Stewart, J.K. and H.M. Couey. 1976. Hydrocooling vegetables. A practical guide to predicting final temperatures and cooling times. USDA Mktg. Res. Rpt. 637.

Stretch, A.W. and M.J. Ceponis. 1983. Influence of water immersion time and storage period on black rot development in cold-stored, water harvested cranberries. Plant Dis. 67:21-23.

Stretch, A.W. and M.J. Ceponis. 1986. Fungal and physiological breakdown in six cranberry cultivars following water harvesting and cold storage. HortScience 21:265-267.

Swanson, B.G. and K.G. Weckel. 1975. Refrigerated storage of fresh cranberries. J. Food Sci. 40:259-261.

Thompson, J.F. 1996. Forced air cooling. Perishable Handling Nwslt. 88:2-11.

Wright, R.C., J.B. Demaree, and M.S. Wilcox. 1937. Some effects of different storage temperatures on the keeping of cranberries. Proc. Amer. Soc. Hort. Sci. 34:397-401.
Physiological

Effects of Physical Postharvest

Treatments on Insects

\author{
Lisa G. Neven
}

Summary. As concerns about the safety of our food supply increase along with concerns about the impact of agricultural chemicals on our environment, the development of nonchemical quarantine treatments to meet export requirements become increasingly necessary. The types of physical treatments used have been largely determined by commodity tolerances and processing practices. The most common physical treatments use temperature extremes such as heat $\left[>40{ }^{\circ} \mathrm{C}\left(104.0{ }^{\circ} \mathrm{F}\right)\right]$ and cold $\left[<10{ }^{\circ} \mathrm{C}\right.$ $\left.\left(50.0{ }^{\circ} \mathrm{F}\right)\right]$. Other physical treatments commonly include the use of controlled or modified atmospheres (low oxygen, elevated carbon dioxide). Current technology has led to investigations in the application of energy to control infesting insects. These treatments include ionizing radiation, microwaves, ultraviolet radiation, infrared radiation, radio frequency, electron beam, $\mathrm{X}$-rays, and electricity. Although the effects of these physical treatments can impact commodity quality, the goal of the treatments is to kill infesting (real or in certain instances, potential) insects to meet quarantine requirements. The effects of physical treatments on insect mortality and fecundity are discussed.

$\mathrm{P}$ ostharvest quarantine treatments of fresh fruits and vegetables are often necessary to eliminate arthropod pests which may reside within or upon the commodity. The elimination of these pests is necessary to maintain and gain access to many export markets which restrict movement of host commodities, which may harbor pests they deem a threat to their agricultural industry. These quarantine restrictions have been overcome,

USDA-ARS, Yakima Agricultural Research Laboratory, 5230 Konnowac Pass Road, Wapato, WA 98951; e-mail neven@yarl.ars.usda.gov. in the past, by the application of fumigants, such as ethylene dibromide (EDB) or methyl bromide $(\mathrm{MB})$. Although highly effective in eliminating arthropods, these chemicals pose a threat to human health, as is the case with EDB (U.S. Environmental Protection Agency, 1984), or the environment, as is the case with MB (United Nations Environmental Programs, 1992). In addition, consumers have become increasingly aware of the potential effects of pesticide residues on fresh fruits and vegetables, and are demanding more natural (nonchemical) approaches to food production and processing. In this vein, horticulturists and entomologist have pursued the development of nonchemical or physical treatments for pest removal.

Physical postharvest treatments are not new to the area of quarantine security. In fact, before the development of fumigants, physical treatments were the only way to kill pests in horticultural commodities. There are also a number of commodities, such as avocados (Persea americana) (Armstrong, 1994) and pears (Pyrus communis) (Drake and Moffitt, 1992), which do not respond well to chemical fumigants. For these and other sensitive commodities, physical treatments remain the only avenue available for achieving quarantine security. The most common physical treatments include temperature extremes (high and low), controlled atmospheres (low oxygen, high carbon dioxide), and high energy (radio frequency, ionizing radiation). The different types of treatments and the effects on insects will be discussed.

\section{High temperature}

High temperature treatments include hot water dips, drenches and sprays, hot air (static), hot forced air, and vapor heat. Although microwave and radio frequency may also be included in this category since they work by conversion of electromagnetic energy into heat, they will be discussed in another section. The important factors affecting the efficacy of heat treatments are 1) the target temperature of the treatment, 2) the rate of heating, 3 ) the duration of the heat treatment, and 4) insect milieu, meaning the location of the insect in the commodity and the condition of the commodity surrounding the insect. The interrelationship of these factors is extremely important to remember when considering a heat treat- 
ment for quarantine purposes. A heat treatment may be efficacious at a lower temperature if the heating rate is sufficient to circumvent acclimation and if the duration is sufficient to overcome the insect's ability to compensate for the heatload (Neven, 1998a, 2001a). Temperature is important when it is below a critical thermal limit to which the insect is naturally acclimatized or genetically predisposed to tolerate. For heat treatments below this critical thermal limit, the rate or duration of the treatment become inconsequential (Neven and Rehfield, 1995). The fourth factor, insect milieu, is clearly as important a factor as the other three. Location within the commodity will affect total thermal experience (temperature, rate, and duration), whereas the condition of the commodity can influence insect tolerance. Interesting examples are found in work by Shellie and Mangan (2000), Hallman (1996), and Hansen and Sharp (2000). Shellie and Mangan (2000) found that the heating rates and final target temperatures of citrus (Citrus spp.) fruit varied with the type of heat treatment (hot air, vapor heat, and hot water). Fruit internal atmospheres also varied in relation to treatment type. Alteration of atmospheres during a heat treatment can greatly influence insect response. Hallman (1996) found that artificial hot water dips, a method commonly used to determine insect thermal responses and model potential heat treatments, showed varied results when the water was replaced with solutions of natural fruit juices or citric acid. Insect survival was higher when treated in water and citric acid as opposed to treatments conducted in natural fruit juices. Hansen and Sharp (2000) found that mortality of third instar caribbean fruit fly (Anastrepha suspensa) from heat treatments in air, water, artificial diet or fruit pulp blends varies, with treatments in air and water resulting in the highest and lowest survival, respectively.

The effects of high temperature treatments on insects are manifested in a myriad of physiological and developmental responses (Neven, 200la). High temperatures can effect metabolism, respiration, neural function, and endocrine systems. Enzyme activity can be greatly altered by small changes in temperature (Hochachka and Sommero, 1984; Hoffman, 1984), and the activity of membrane-bound enzymes are subject to changes in the fluidity of the phospholipid bilayer, which is always dependent on thermal changes (Hochachka and Sommero, 1984). Respiration effects are manifested by initial elevation of oxygen consumption as the temperature increases, up to a critical thermal limit, followed by a short decrease, possibly to conserve stored energy. If thermal stress continues, mortality occurs (Neven, 1998b, 2001a). There is a growing body of evidence that oxygen is critical for insect thermal stress response (Moss and Jang, 1991; Neven and Mitcham, 1995; Sonderstrom et al., 1992; Whitting et al., 1991; Yocum and Denlinger, 1994,). Anoxia can interfere with the generation of ATP, through catabolism of lipids and carbohydrates, which is critical for maintaining elevated metabolism in response to the heat load (Neven, 2001a). Changes in neural and endocrine function as a result of elevated temperatures may be due to the sensitivity of these systems to membrane fluidity and signal transduction. Other effects of elevated temperature on the endocrine system can be manifest as developmental abnormalities, defects, delays in development, and sterility (Denlinger and Yocum, 1998; Neven, 2001a).

There are two general theories on the models of thermal damage. One by Roti Roti (1982) suggests that the effect of heat on macromolecules (proteins, DNA, carbohydrates, etc.) is the critical element of thermal damage. The other theory by Bowler (1987) points to damage of the cell membrane as the critical event. Perhaps the reality of the effect is a matter of degrees. The more complex an organism, the more systems there are which are interrelated to support life. If one looks at this problem in an evolutionary light, then macromolecules should be the most thermal tolerant followed in decreasing tolerance by cells, tissues, and lastly the whole organism (Neven, 2001a).

\section{Low temperature}

Low temperature treatments usually imply extended periods of exposure to temperatures at or just above freezing $\left[0{ }^{\circ} \mathrm{C}\left(32.0^{\circ} \mathrm{F}\right)\right]$. However, for some tropical and sub-tropical commodities, cold storage is performed at temperatures somewhere between 10 to $12{ }^{\circ} \mathrm{C}$ $\left(50.0\right.$ to $53.6^{\circ} \mathrm{F}$ ) for tropical and 4 to 7 ${ }^{\circ} \mathrm{C}\left(39.2\right.$ to $\left.44.6{ }^{\circ} \mathrm{F}\right)$ for sub-tropical fruits (Paull and McDonald, 1994). For many durable commodities, like grains, cold storage may be as low as $-23^{\circ} \mathrm{C}(-$ $\left.9.4^{\circ} \mathrm{F}\right)$ (Mason and Strait, 1998). The effects of low temperature on insects manifest themselvesin reduced metabolism and respiration leading to a general loss of adenosine 5 '-triphosphate (ATP) production. Also, insect development and neural functions are greatly inhibited during prolonged cold exposure. Cell ionic balance and membrane potential can be greatly affected due to loss of membrane integrity during prolonged exposure to low temperatures. This can lead to reversible chill torpor and chill coma (results of neuromuscular dysfunction), irreversible chill shock, oxidative stress (due to the effects of low temperature on superoxide dismutase), cellular and membrane dysfunction, and also reduced fertility (Denlinger and Lee, 1998). As the duration of the cold exposure is extended, these factors lead to the demise of the insect.

\section{Controlled atmospheres}

Controlled atmosphere (CA) usually implies an alteration in the levels of oxygen $\left(\mathrm{O}_{2}\right)$ and carbon dioxide $\left(\mathrm{CO}_{2}\right)$ from those present in normal air [21\% $\mathrm{O}_{2}$ and $0.03 \% \mathrm{CO}_{2}$ at standard temperature and pressure (STP)]. Most CA treatments employ either low $\mathrm{O}_{2}$ or elevated $\mathrm{CO}_{2}$, or a combination of both. The temperature at which CA is used varies greatly. There are treatments performed at room temperatures [ 18 to 23 ${ }^{\circ} \mathrm{C}\left(64.4\right.$ to $\left.\left.73.4^{\circ} \mathrm{F}\right)\right]$, low temperatures (near $0^{\circ} \mathrm{C}$ ), or at elevated temperatures [38 to $50{ }^{\circ} \mathrm{C}\left(100.4\right.$ to $\left.122.0{ }^{\circ} \mathrm{F}\right)$ ] (Neven, 2001b). The duration of the treatments varies in relation to the temperature at which it is performed. Generally, the higher the temperature, the shorter the duration of the treatment.

The general principle underlying the effects of CA on insects is that of asphyxiation or carbonic acid build-up. However, low levels of $\mathrm{O}_{2}$ at low temperatures do not have as dramatic effect

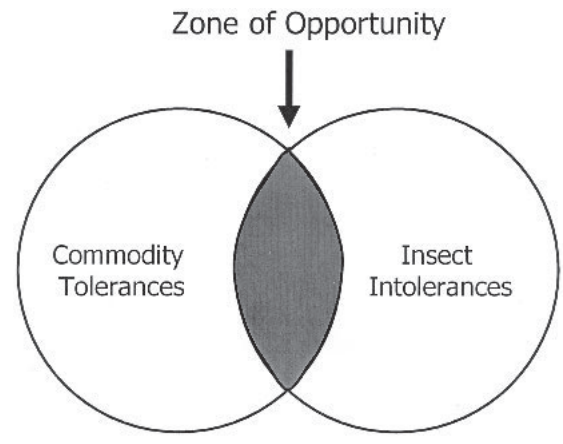

Fig. 1. Goal for the development of physical postharvest quarantine treatments for horticultural commodities. 
on insect mortality as does high $\mathrm{CO}_{2}$ (Neven, 2001b). At low temperatures, the metabolic demand for $\mathrm{O}_{2}$ in the insect is greatly reduced as well as neural function which controls respiration (Slama and Neven, 2001). However, elevated levels of $\mathrm{CO}_{2}$ can cause an acid/base imbalance and lead to disruption of electron transport and other metabolic pathways.

Friedlander (1983) described the effects of elevated levels of $\mathrm{CO}_{2}$ on insect metabolism. They showed that $\mathrm{CO}_{2}$ at $>10 \%$ stopped the production of nicotinamide adenine dinucleotide phosphate (NADPH) which is important for detoxification in the cell. The cell energy charge was reduced, slowing processes requiring ATP. They also found that high levels of $\mathrm{CO}_{2}$ inhibited the regeneration of choline to acetylcholine. In addition, the production of glutathione (an important component of $\mathrm{MB}$ detoxification) was reduced (Friedlander, 1983).

Perhaps the most interesting body of work comes from using scanning calorimetry to measure metabolic heat rate (MHR) from pupae of omnivorous leaf rollers (Platyona stultana) (Zhou et al., 2000, 2001). Zhou et al. (2000) found that the heat rate decreased with decreasing $\mathrm{O}_{2}$ levels. They determined that the critical $\mathrm{O}_{2}$ levels $\left(\mathrm{P}_{\mathrm{c}}\right)$ increased with increasing temperature. They also found that the heat rate decreased rapidly with increasing $\mathrm{CO}_{2}$ levels up to $20 \%$, but changed little up to $79 \% \mathrm{CO}_{2}$. Furthermore, they found additive effects between $\leq 5 \% \mathrm{CO}_{2}$ and $\geq 4 \% \mathrm{O}_{2}$. They concluded that high susceptibility to $\mathrm{CO}_{2}$ at high temperatures was related to the high metabolic heat rates and that the response to low levels of $\mathrm{O}_{2}$ was related to metabolic arrest and anaerobic metabolism.

In subsequent studies, Zhou et al. (2001) found a decrease in the metabolic heat rate with increasing $\mathrm{CO}_{2}$ and decreasing $\mathrm{O}_{2}$ levels. Pupae were able to recover if the metabolic heat rate was reduced to only $30 \%$, but that death of the pupae occurred when the MHR was reduced to $50 \%$. They found equivalent mortality between $5 \% \mathrm{CO}_{2}$ and $6 \% \mathrm{O}_{2}$, and $10 \% \mathrm{CO}_{2}$ and $2 \% \mathrm{O}_{2}$. They concluded that the effects of low $\mathrm{O}_{2}$ and elevated $\mathrm{CO}_{2}$ were manifested primarily on increased membrane permeability.

\section{High energy}

As stated in the section on high temperature, high energy treatments of microwave and radio frequency may be generally regarded as thermal treatments. However, interesting results from Tang et al. (2000) and Wang et al. (2001) indicate that this may not be the only effect of these treatments on insects. The difference in thermal conductivity or dielectric constant between the insect and the commodity which it infests may result in a differential heating of the insect, and may cause other disruptions in insect metabolism and/or structures related to the transfer of energy at specific frequencies (Ikadela et al., 1999, 2000; Tang et al., 2000; Wang et al., 2001).

Irradiation is perhaps the moststudied of the high energy physical treatments for disinfestation purposes. Radiation encompasses source irradiators (cobalt isotope ${ }^{60} \mathrm{Co}$ and cesium isotope $\left.{ }^{137} \mathrm{Cs}\right)$, electron beam $(\leq 10 \mathrm{mV})$, and $\mathrm{x}$ rays $(\leq 5 \mathrm{mV})$ up to doses of $1,000 \mathrm{~Gy}$. The effects of these treatments have been documented for a wide range of insect pests, especially those of quarantine concern. Most of the effects of irradiation appear on the genetic level, generally causing sterility, delay of development, and morphological deformities (Ignatowicz and WroblickaSysiak, 1996; Nation et al., 1995a; Szcepanik and Ignatowicz, 1995). However, differences in behavior, protein banding patterns, and gene and protein expression have also been noted (Ignatowicz 1996a, 1996b; Ignatowicz and Zaedee, 1996).

Perhaps the most disturbing result of the use of ionizing radiation for quarantine treatments is that at the doses used, direct mortality of the target pest insect is not always achieved. Direct mortality is normally the bellwether of quarantine efficacy. Therefore, appropriate research must document the biological neutralization of the target pest. Confidence limits must be established and target points must be clearly determined for the acceptance of such treatments. Confidence limits, such as Probit 9 (32 survivors out of $1,000,000$ treated with $95 \%$ confidence limits), may or may not be achievable. Often, new guidelines for risk assessment must be detailed. Target points, such as adult sterility, zero adult eclosion, or zero pupation must be clearly identified by the regulatory agencies. One, but perhaps not all, of these target points may be achievable for most pest arthropods. The determining factor is resistance to the treatment.
It has been proposed that a molecular or biochemical marker could be used to determine whether an insect has indeed been treated with the appropriate dose of radiation to render it biologically inactive. Initial research by Nation et al. (1995b), indicated that caribbean fruit flies, irradiated at the first instar could be evaluated at the third instar using a simple melanization test to determine if the appropriate treatment was applied. However, the timing between irradiation and evaluation of the insect is too long for most perishable commodities. Plus, what is the probability of finding a third instar which was treated as a first instar in a sample load of fruit? Other research by Neven and Morford (1998) and Ignatowicz and Zaedee (1996) indicated that this melanization test was not useful for evaluating irradiated codling moth (Cydia pomonella) or confused flour beetle (Tribolium confusum).

\section{Summary}

The effects of physical treatments on insects is as varied as the treatments themselves. For many treatments, the reported affected systems are variable which is most likely dependent upon on how scientists chose to look at the effects. The key to developing physical quarantine treatments is to pinpoint the physiological weakness of the insect or to capitalize on the differences in the physiological responses of the horticultural commodity and the infesting insect (Fig. 1). For example, many plants and fresh horticultural products respond to environmental stress in a stock manner, such that exposure to one stress, say a heat shock, can predispose the plant to withstand a subsequent stress, say a cold treatment (Neven et al., 1992, 1993). Insects, on the other hand, do not typically exhibit this cross-protection phenomenon (Neven, 1994, 2001a). This difference in physiological response can be exploited to develop a quarantine treatment.

\section{Literature cited}

Armstrong, J.W. 1994. Tropical and subtropical fruits, p. 275-290. In R.E. Paull and J.W. Armstrong (eds.). Insect pests and fresh horticultural products: Treatments and responses. CAB Intl., Wallingford, U.K.

Bowler, K. 1987. Cellular heat injury. Are membranes involved? p 157-185. In: K. Bowler and B.J Fuller (eds.). Temperature and animal cells. Soc. Expt. Biol. Symp. 41, Cambridge, U.K. 
Denlinger, D.L. and R. Lee. 1998. Physiology of cold sensitivity, p. 55-95. In: G.J. Hallman and D.L. Denlinger (eds.). Temperature sensitivity in insects and application in integrated pest management. Westview Press, Boulder, Colo.

Denlinger, D.L. and G.D. Yocum. 1998. Physiology of heat sensitivity, p. 7-54. In: G.J. Hallman and D.L. Denlinger (eds.). Temperature sensitivity in insects and application in integrated pest management. Westview Press, Boulder, Colo.

Drake, S. and H. Moffitt. 1992. Winter pear (Anjou and Bosc) response to methyl bromide fumigation. HortScience 27:813-816.

Friedlander, H. 1983. Biochemical reflections on a nonchemical control method: The effect of controlled atmosphere on the biochemical processes in stored products insects, p. 471-486. In: Proceedings, third international working conference on stored products entomology. Kan. State Univ., Manhattan.

Hallman, G.J. 1996. Mortality of third instar caribbean fruit fly (Diptera: Tephritidae) reared in diet or grapefruits and immersed in heated water or grapefruit juice. Fla. Entomol. 79(2):168-172.

Hansen, J.D. and J. Sharp. 2000. Thermal death of third instars of the caribbean fruit fly (Diptera: Tephritidae) treated in different substrates. J. Entomol. Sci. 35(2):196-204.

Hoffman, K.H. 1984. Metabolic and enzyme adaptation to temperature, p. 1-32. In: K.H. Hoffman (ed.). Environmental physiology and biochemistry of insects. Springer Verlag, Berlin.

Hochachka, P.W. and G.N. Sommero. 1984. Temperature adaptation, p. 355-449. In: P.W. Hochachka and G.N. Sommero (eds.). Biochemical adaptation. Princeton Univ. Press, Princeton, N.J.

Ignatowicz, S. 1996a. Identification of irradiated insects: alterations in total proteins of irradiated adults of the confused flour beetle, Tribolium confusum DuVal. (Coleoptera: Tenebrionidae). Nukleonika 4l(4):83-96.

Ignatowicz, S. 1996b. Susceptibility of diapausing larvae of the khapra beetle, Trogoderma granarium Everts, to gamma radiation. Agriculture 31:47-52.

Ignatowicz, S. and I.H. Zaedee. 1996. Reduced melanization after death in larvae of the confused flour beetle, Tribolium confusum, as a result of the irradiation treatment. Polish J. Entomol. 65:51-59.

Ignatowicz, S. and M. Wroblicka-Sysiak. 1996. Reproductive performance of the bulb mite, Rhizoglyphus echinopus (F. et R.), after treatment with low doses of gamma radiation. Nukleonika 4l(1):81-88.

Ikediala, J.N., J. Tang, L.G. Neven, and S.R. Drake. 1999. Quarantine treatment of cherries using $915 \mathrm{MHz}$ microwaves: Temperature mapping, codling moth mortality and fruit quality. Postharvest Biol. Technol. 16:127-137.

Ikediala, J.N., J. Tang, S.R. Drake, and L.G. Neven. 2000. Dielectric properties of apple cultivars and codling moth larvae. Trans. Amer. Soc. Agr. Eng. 43(5):1175-1184.
Mason, L.S. and C.A. Strait. 1998. Stored product integrated pest management with extreme temperatures, p. 141-177. In: G.J. Hallman and D.L. Denlinger (eds.). Temperature sensitivity in insects and application in integrated pest management. Westview Press, Boulder, Colo.

Moss, J.I. and E.B. Jang. 1991. Effects of age and metabolic stress on heat tolerance of Mediterranean fruit fly (Diptera: Tephritidae) eggs. J. Econ. Entomol. 84:537-541.

Nation, J.L., B.J. Smittle, K. Milne, and T.M. Dykstra. 1995a. Influence of irradiation on development of caribbean fruit fly (Diptera: Tephritidae) larvae. Ann. Entomol. Soc. Amer. 88:348-352.

Nation, J.L., B.J. Smittle, and K. Milne. 1995b. Radiation-induced changes in melanization and phenoloxidase in caribbean fruit fly larvae (Diptera: Tephritidae) as the basis for a simple test of radiation. Ann. Entomol. Soc. 88:201205 .

Neven, L.G., D.W. Haskell, C.L. Guy, N. Denslow, P. Klein, L. Green, and A. Silverman. 1992. Association of a $70 \mathrm{kDa}$ heat shock cognate with acclimation to cold. Plant Physiol. 99:1362-1369.

Neven, L.G., D.W. Haskell, A. Hofig, Q.B. Li, and C.L. Guy. 1993. Characterization of a gene responsive to low temperature and water stress. J. Plant Mol. Biol. 21:291-305.

Neven, L. 1994. Combined heat treatment and cold storage effects on mortality of fifth-instar codling moth (Lepidoptera: Tortricidae). J. Econ. Entomol. 87:1262-1265.

Neven, L. and L. Rehfield. 1995. Comparison of pre-storage heat treatments on fifth instar codling moth (Lepidoptera: Tortricidae) mortality. J. Econ. Entomol. 88(5):1371-1375.

Neven. L. and E. Mitcham. 1995. CATTS: Controlled atmosphere/temperature treatment system. A novel approach to the development of quarantine treatments. Amer. Entomol. $42(1): 56-59$

Neven, L.G. 1998a. Effects of heating rate on the mortality of fifth instar codling moth. J. Econ. Entomol. 91:297-301.

Neven, L.G. 1998b. Respiratory response of fifth instar codling moth to rapidly changing temperatures. J. Econ. Entomol. 91:302-308.

Neven, L.G. and Morford, M. W. 1998. Effects of irradiation on phenoloxidase levels in codling moth larvae. J. Econ. Entomol. 91:534-538.

Neven, L.G. 2001a. Insect physiological responses to heat. Postharvest Biol. Technol. 21:103-111.

Neven, L.G. 2001b. Controlled atmosphere treatments for quarantine security, p. 36-41. In: Proceedings of the North American Plant Protection Organization Workshop on Phytosanitary Alternatives to Methyl Bromide. N. Amer. Plant Protection Org. Bul. 19.

Paull, R.E. and R.E. McDonald. 1994. Heat and cold treatments, p. 191-227. In: R.E. Paull and J.W. Armstrong (eds.). Insect pests and fresh horticultural products: Treatments and responses. CAB Intl., Wallingford, U.K.
Roti Roti, J.L. 1982. Heat-induced cell death and radiosenstization: Molecular mechanisms, p. 3-10. In: Dethlefsen, L.A., Dewey, and W.C. (eds.). Proceedings of the 3rd International Symposium: Cancer Therapy by Hyperthermia, Drugs and Radiation. Natl. Cancer Inst. Monogr. 61 .

Shellie, K.C. and R.L. Mangan. 2000 Postharvest disinfestations heat treatments: response of fruit and fruit fly larvae to different heating media. Postharvest Biol. Technol. 21:5160.

Slama, K. and L. Neven. 2001. Active regulation of respiration and circulation in pupae of the codling moth (Cydia pomonella). J. Insect Physiol. 47:1321-1336.

Sondersom, E.L., D.G. Brandal, and B. Mackey. 1992. High temperature combined with carbon dioxide enriched or reduced oxygen atmospheres for control of Tribolium castaneum (Herbst) (Coleoptera: Tenebrionidae). J. Stored Product Res. 28:235-238.

Szczepanik, M. and S. Ignatowicz. 1995. Changes in the midgut of larvae of the khapra beetle, Trogoderma granarium Everts, induced by gamma radiation. Bul. Polish Acad. Sci. 43(3):205-209

Tang, J., S. Wang, J.D. Hansen, and R. Cavalieri. 2000. High-temperature-short time thermal quarantine methods. Postharvest Biol. Technol. 21:129-145.

United Nations Environmental Programs, Montreal Protocol Assessment Supplement. 1992. Methyl bromide: Its atmospheric science, technology and economics. Synthesis report of the methyl bromide interim scientific assessment and methyl bromide interim technology and economic assessment. U.S. Govt. Printing Office, Wash., D.C.

U.S. Environmental Protection Agency. 1984. Rules and regulations. Revocation of tolerance ethylene dibromide. Fed. Reg. 49:2208222085

Wang, S., J. Tang, J.D. Hansen, E. Mitcham, R. Mao, and B. Swanson. 2001. Radio frequency treatments to control codling moth in in-shell walnuts. Postharvest Biol. Technol. 22:29-38.

Whitting, D.C., S.P. Foster, J.H. Maindonald. 1991. Effects of oxygen, carbon dioxide, and temperature on the mortality responses of Epiphyaspostivittana(Lepidoptera: Tortricidae). J. Econ. Entomol. 84:1544-1549.

Yocum, G.D. and D.L. Denlinger. 1994. Anoxia blocks thermotolerance and the induction of rapid cold hardening in the flesh fly Sarcophaga crassipalpis. Physiol. Entomol. 19:152-158.

Zhou, S., R.S. Criddle, and E.J. Mitcham. 2000. Metabolic response of Platynota stultana pupae to controlled atmospheres and its relation to insect mortality response. J. Insect Physiol. 46:1375-1385.

Zhou, S., R.S. Criddle, and E.J. Mitcham. 2001. Metabolic response of Platynota stultana pupae under and after extended treatment with elevated $\mathrm{CO}_{2}$ and reduced $\mathrm{O}_{2}$ concentrations. J. Insect Physiol. 47:401-409. 